\title{
REACTION OF SOME SUGARBEET VARIETIES TO THE INFESTATION WITH SOME INSECTS AND FINAL YIELD
}

\author{
EL-RAWY, A. M. ${ }^{1}$ AND G. A. SHALABY ${ }^{2}$ \\ 1. Plant Protection Research Institute, Agric. Res. Center, Egypt. \\ 2. Sugar Crops Research Institute, Agric. Res. Center, Egypt.
}

(Manuscript received 14 June 2011)

\begin{abstract}
Some ecological studies on sugarbeet insect pests, were conducted in Sakha Agric. Res. Station, Kafr El-Sheikh Governorate, during the two growing seasons 2009/10 and 2010/11 to evaluate eleven sugarbeet varieties ; Francesca, Helsinki, Revel, Sibel and Univers (monogerm); Diamond, Farida, Helioses, Hercule, Maghrible and Pleno (polygerm) for resistance to main insects of sugarbeet plants (Pegomya mixta, Cassida vittata and Scrobipalpa ocellatella) and high yielding potential. The results revealed that two varieties; Hercule and Helsinki had the least infestation by $P$. mixta. On the other hand, three varieties ; Helsinki, Francesca and Helioses had the least infestation by $C$. vittata while each of Helsinki, Sibel and Francesca had the least infestation by $S$. ocellatella. Finally, two varieties Maghrible and Revel proved moderate insect population and in the same time increased root (24.44 and 23.75 ton/fed., respectively) and sugar (4.46 and 4.39 ton/fed., respectively) yield.
\end{abstract}

\section{INTRODUCTION}

In Egypt, sugarbeet, Beta vulgaris L. (Family: Chenopodiacea) is considered the second important sugar crop after sugarcane. In 2009, the total cultivated area 248871 feddan in the old and newly lands, produced about 5138190 ton with an average yield of 20.646 ton/fed. (Sugar Crops Council Report, Jan. 2010). Under Egyptian ecosystem, sugarbeet plants are subjected to be attacked by numerous insect pests during its different group stages. So many authors are attracted to study a group of insect pests cause serious problems for growers and cause yield reductions (Bassyouny and Khalafalla, 1996, Ebieda, 1997 and 1998 and Ebieda et al., 1998). In recent years, the beet fly Pegomya mixta, tortoise beetle Cassida vittata and beet moth Scrobipalpa ocellatella have become serious pests of the sugarbeet (Mousa, 2005, Amin et al., 2008 and Abou-Elkassem, 2010). The objective of the present study is to evaluate some cultivars of sugarbeet for tolerance against three serious pests, P.mixta, C.vittata and S.ocellatella in order to identify new source of tolerance to search for safer methods rather than toxicants and reducing yield losses due to these insect pests in relation to yield and quality. However, the present study aimed to determine the effect of sugarbeet varieties on the abundance of the three previously mentioned insects and increase yield potential. 


\section{MATERIALS AND METHODS}

Field studies were carried out at Sakha Agric. Res. Station, Kafr El-Sheikh Governorate during two successive seasons 2009/10 and 2010/11 to evaluate the relative susceptibility of eleven sugarbeet varieties to the infestation with the main insects of sugarbeet plants (five monogerm varieties namely, Francesca, Helsinki, Revel, Sibel and Univers and six polygerm varieties namely, Diamond, Farida, Helioses, Hercule, Maghrible and Pleno) and yield and quality.

Susceptibility of eleven sugarbeet varities was evaluated to the infestation with P. mixta (larvae), C. vittata (larvae and adults) and S. ocellatella (larvae). The experimental area was divided into plots each of $42 \mathrm{~m}^{2}$ (1/100 feddan), each variety was replicated four times in a complete randomized block design and received the usually recommended agricultural treatment. No chemicals were used for controlling sugarbeet insect pests throughout the whole period of the study, the eleven sugarbeet varieties were sown on October $27^{\text {th }}$ of both seasons.

Sampling started one month after sowing and continued until harvesting. The plants were visually examined and the insect pests were counted and recorded biweekly on 40 plants (10 plants/replicate) selected randomly for each variety to determine the percentage of leaves infestation, no. of blotches \& no. of $P$. mixta larvae; no. of $C$. vittata larvae \& adults and no. of $S$. ocellatella larvae.

At harvest, 25 sugarbeet plants were also randomly taken from the four middle ridges of each plot to determine: Foliage weight and the roots were directly pulled, cleaned and weighed. Sucrose percentages were estimated according to the procedure of Le Docte (1927) in Delta sugar company, Kafr El-Skeikh Governorate. Sugar yield in Tons/fed. = Yield of roots in tones $/$ fed. $X$ adjusted sucrose percentages.

Statistical analysis was carried out to obtain any significant differences among means of the treatments according to Duncan's (1955) method through SAS computer program.

\section{RESULTS AND DISCUSSION}

\section{Influence of some sugarbeet varieties on the infestation level with main insect pests:}

The susceptibility of eleven sugarbeet varieties; Francesca, Helsinki, Revel, Sibel and Univers (monogerm), Diamond, Farida, Helioses, Hercule, Maghrible and Pleno (polygerm) to infestation with Pegomya mixta, Cassida vittata and Scrobipalpa ocellatella 
were studied at Kafr El-Sheikh region during two successive seasons 2009/10 and 2010/11.

\subsection{Sugarbeet fly, P. mixta:}

Data illustrated in Tables (1, $2 \& 3)$ showed that, the highest general mean of average of infested leaves, no. of blotches and no. of larvae was recorded on Pleno variety $(25.63 \%, 61.39$ blotches and 72 larvae/10 plants, respectively) followed by Helioses variety (24.55\%,52.08 blotches and 70.3 larvae/10 plants, respectively), then Farida variety $(18.37 \%, 45.53$ blotches and 63.5 larvae/10 plants, respectively). On the other hand Hercule and Helsinki varieties demonstrated the lowest $P$. mixta infestation on the basis of general mean of percentages of infested leaves (9.03 and $9.50 \%$, respectively), blotches (24.23 and 30.49/10 plants, respectively) and larvae (37.2 and 34.2/10 plants, respectively). The statistical analysis indicated that there were significant differences among the tested sugarbeet varieties to infestation with $P$. mixta and the polygerm varieties were relatively susceptible to infestation with $P$. mixta comparing with monogerm varieties. These results are in agreement with those obtained by Zarif and Hegazi (1990), Solouma (1999), Hussein (2001), Mousa (2005), Amin et al. (2008) and Abou-Elkassem (2010).

\subsection{The tortoise beetle, $C$. vittata:}

Results in Tables (1, 2 \& 3 ) indicated significant differences among susceptibilities of the eleven varieties to infestation by $C$. vittata. On the other hand, the polygerm varieties were relatively susceptible to infestation by this insect comparing with monogerm varieties (42.0 and 32.7 larvae \& adults / 10 plants, respectively). The obtained results showed that on the basis of general mean of larvae and adults which represented the feeders and injurious stages of the beet beetle, $C$. vittata, Pleno variety was found to be the most prefer and attractive for both larvae and adults as their general mean recorded 74.2 larvae \& adults / 10 plants, followed by Farida variety (48.1 larvae \& adults / 10 plants). While, Helsinki and Francesca varieties were considered the lowest infested varieties (29.7 and 30.2 larvae \& adults / 10 plants, respectively). These results are in agreement with those obtained by Bassyouny and Khalafallah (1996), Talha (2001), Mousa (2005), Amin et al . (2008) and Abou-Elkassem (2010) . 
Table 1. Effect of sugarbeet varieties on infested leaves by $P$. mixta, $C$. vittata and $S$. ocellatella \& yield and quality during 2009/10 season.

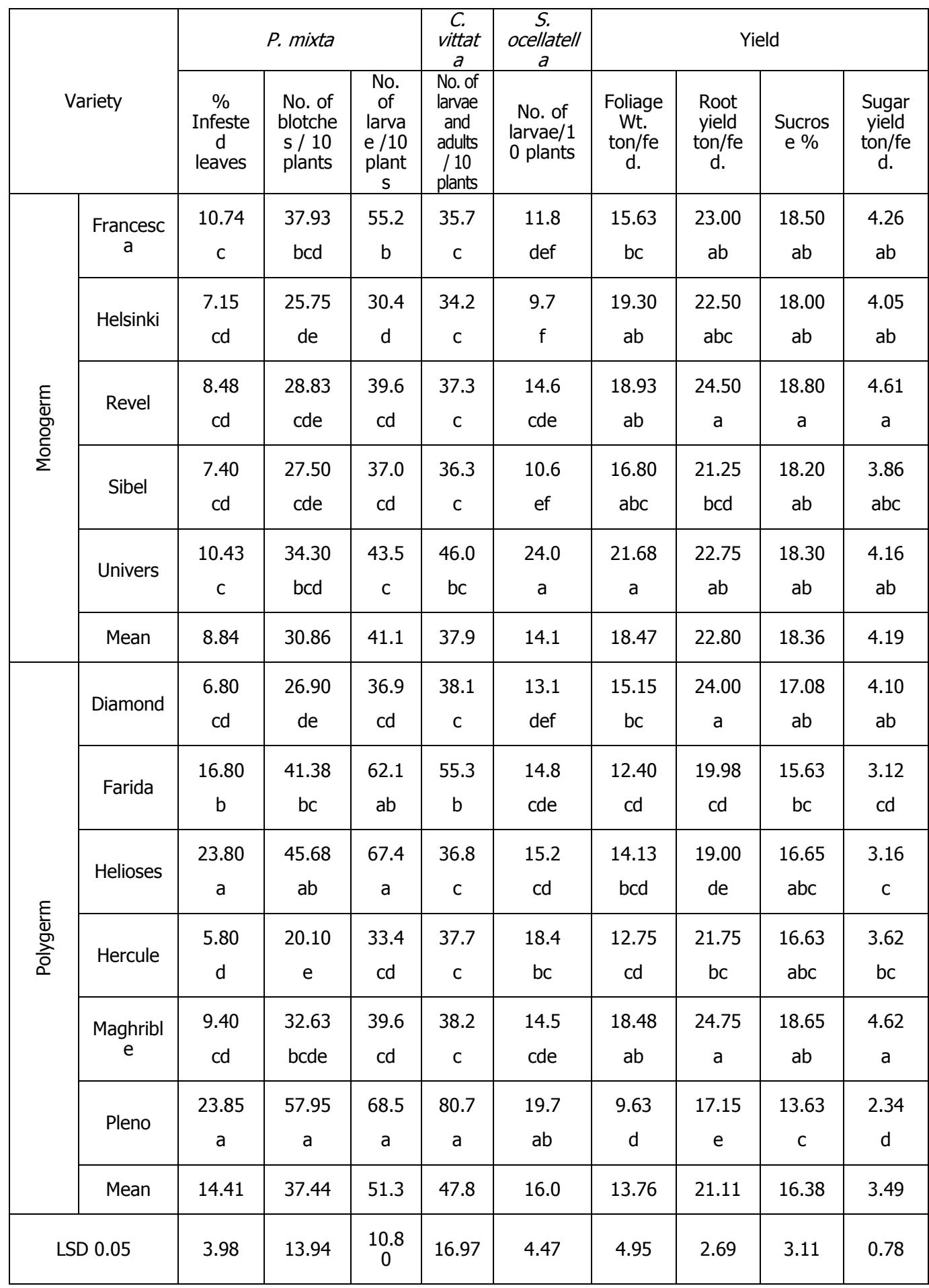


Table 2. Effect of sugarbeet varieties on infested leaves by $P$. mixta, $C$. vittata and $S$. ocellatella \& yield and quality, during 2010/11 season.

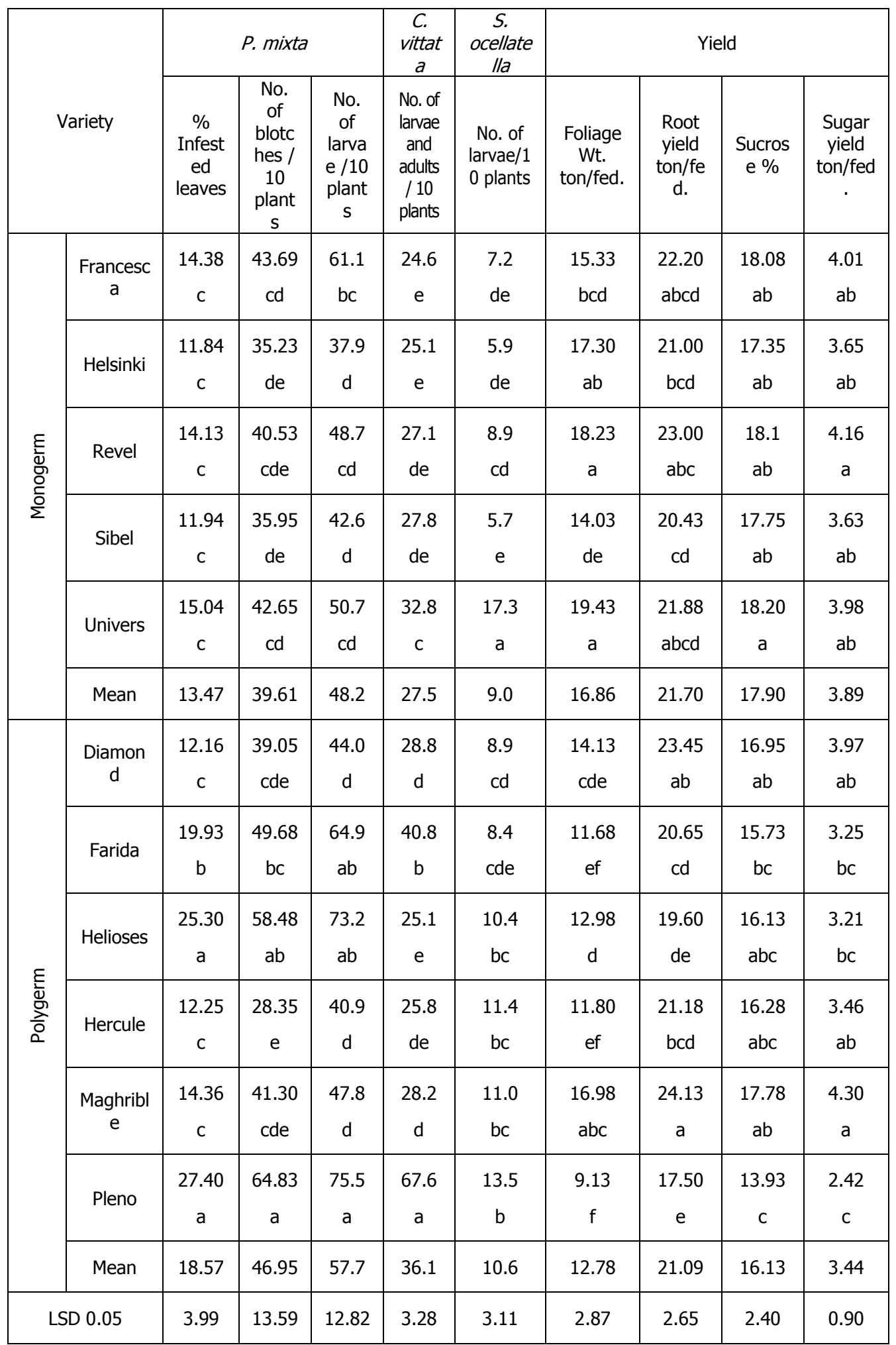

Means followed by the same letter(s) in each column within each treatment are not significant. 
Table 3. Relationship between infested leaves of sugarbeet varieties by $P$. mixta, $C$. vittata and S.ocellatella \& yield and quality (Two seasons combined data).

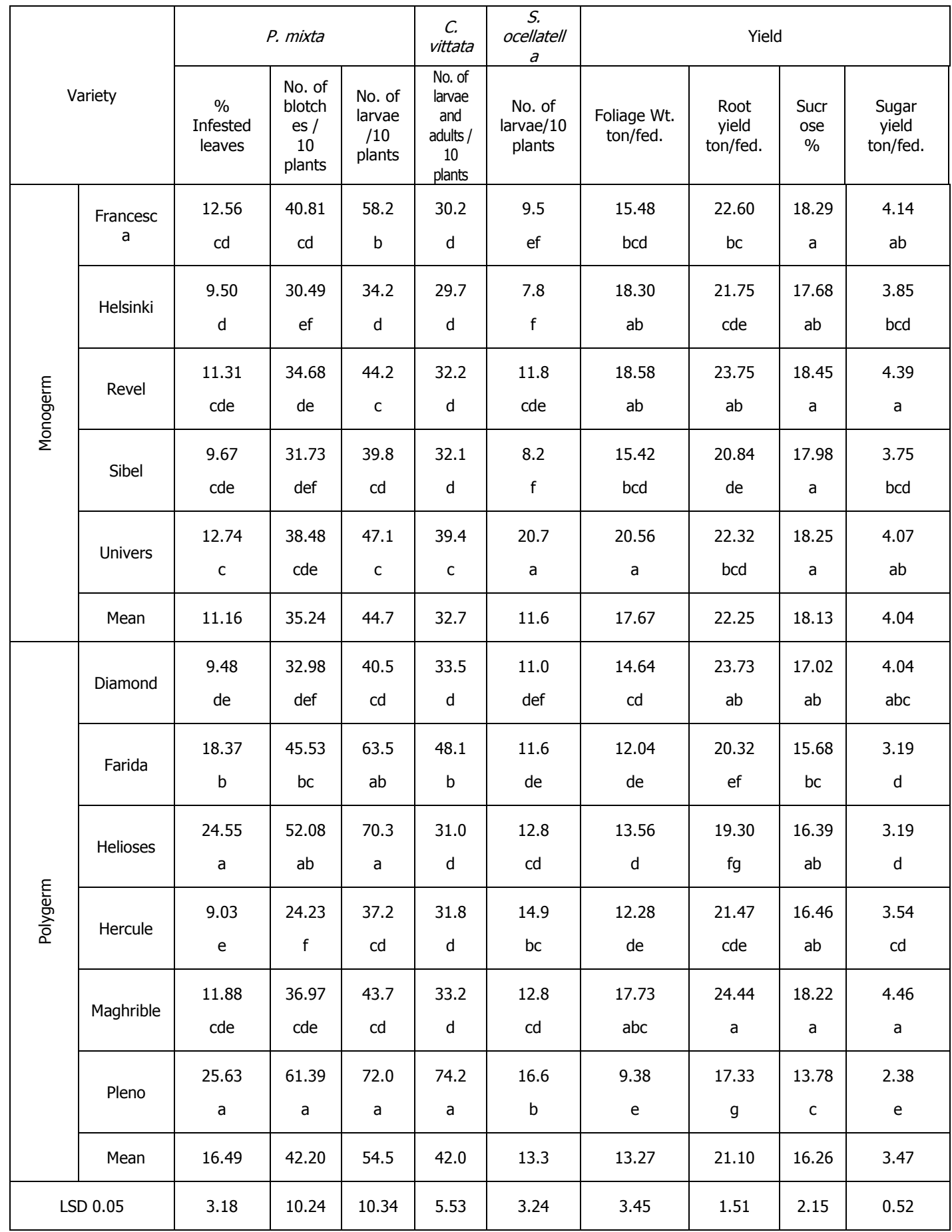

Means followed by the same letter(s) in each column within each treatment are not significant.

\subsection{The beet moth, S, ocellatella:}

The tabulated results indicated that the Univers variety had the highest general mean of larvae (20.7/10 plants) followed by Pleno variety (16.6 larvae/10 plants) then Hercule (14.9 larvae/10plants). Also, results in Tables $(1,2 \& 3)$ revealed that Helsinki and 
Sibel varieties had the lowest general mean of the larval stage (7.8 and 8.2 larvae / 10 plants, respectively). The polygerm varieties were relatively susceptible to infestation with S. ocellatella comparing with monogerm varieties. The statistical analysis showed that there were significant differences among the tested sugarbeet varieties to infestation with S. ocellatella. These results are in agreement with those obtained by Abdel-Ghany (1994), Mousa (2005), Amin et al. (2008) and Abou-Elkassem (2010).

\section{Influence of some sugarbeet varieties on the yield and quality:}

Tables (1, $2 \& 3)$ showed significant differences among the tested sugarbeet varieties in foliage weight, root yield and sugar yield (ton/fed). The monogerm varieties were relatively increase for those comparing with polygerm varieties. The four varieties ; Univers, Revel, Helsinki and Maghrible achieved the highest values of foliage weight (20.56, 18.58, 18.30 and 17.73 ton/fed., respectively). The three varieties Maghrible, Revel and Diamond achieved the highest values of root yield (24.44, 23.75 and 23.73 ton/fed., respectively). The five varieties Maghrible, Revel, Francesca, Univers and Diamond achieved the highest values of sugar yield (4.46, 4.39, 4.14, 4.07 and 4.04 ton/fed., respectively). These results are in agreement with those obtained by Ismail (2002) and Ismail et al. (2002).

A short glance to the data in Table (3) reveals that, two varieties Maghrible and Revel proved moderate insect population and in the same time increased root (24.44 and 23.75 ton/fed., respectively) and sugar (4.46 and 4.39 ton/fed., respectively) yield.

\section{REFERENCES}

1. Abdel Ghany, M. A. 1994. Studies on the beet moth Scrobipalpa ocellatella Boyd. at Kafr El-Sheikh region. M.Sc. Thesis, Fac. Agric., Tanta Univ., 116 pp.

2. Abou Elkassem, A. B. 2010. Ecological and biological studies on some insects of sugarbeet plants at Kafr El-Sheikh Governorate. Ph.D. Thesis, Fac. Agric., Kafr ElSheikh Univ., 209 pp.

3. Amin, A., H. Helmi and S. A. El-Serwy. 2008. Ecological studies on sugarbeet insects at Kafr El-Sheikh Governorate Egypt. Egypt. J. Agric. Res., 86 (6): 21292139.

4. Bassyouny, A. M. and E. M. E. Khalafalla. 1996. Seasonal fluctuations of certain insect pests on three sugarbeet varieties and their chemical control. Alex. Sci. Excha., 17 (4): 381-393.

5. Duncan, D. B. 1955. Multiple range and multible (F) tests-Biometrics, 11-42. 
6. Ebieda, A. M. 1997. Studies on sugarbeet pests. V. Effect of the tortoise beetle, Cassida vittata Vill (Coleoptera: chrysomelidae) on sugarbeet with special reference to the determination of its economic threshold. Adv. Agric. Res., 2 (1): $1-11$.

7. Ebieda, A. M. 1998. Studies on sugarbeet pests. VI. Effect of beet fly, Pegomya mixta Vill on sugarbeet with special reference to the determination of its injury levels and economic threshold. Egypt. J. Agric. Res., 76 (2): 681-692.

8. Ebieda, A. M., M. F. Maareg and A. G. Solouma. 1998. Studies on sugarbeet pests. VIII. Defoliation of sugarbeet plant as a new approach to determine the economic injury levels and the economic thresholds for the some of the main key insect pests. Adv. Agric. Res., 3 (1): 13-30.

9. Hussein, S. H. A. 2001. Ecological studies on certain insect pests attacking sugarbeet crop in Fayoum Governorate. M.Sc. Thesis, Fac. Agric., El-Fayoum Cairo Univ., 131 pp.

10. Ismail, A. M. A. 2002. Evaluation of some sugarbeet varieties under different nitrogen levels at El-Fayoum. Egypt. J.Appl. Sci., 17 (2): 75-85.

11. Ismail, A.M.A., Kh.A. Aboushady and S.M. Allam 2002. Response of some sugarbeet varieties to methods of potassium application. Egypt. J. Appl. Sci., 17 (2): 86-101.

12. Le Docte, A. 1927. Commercial determination of sugar in beet root using the Sacks Le Docte Int. Sugar J., 29: 488-492.

13. Mousa, E. A. 2005. Studies on sugarbeet main insects and their safety control methods. Ph.D. Thesis, Fac. Agric., Mansoura Univ., 294 pp.

14. Solouma, A. G. 1999. Sugarbeet fly, Pegomya mixta Vill. behaviour of egg laying and phenology. Alex. J. Agric. Res., 44 (3): 311-328.

15. Talha, E. A. M. M. 2001. Integrated pest management of sugarbeet insects. M.Sc. Thesis, Fac. Agric., Mansoura Univ., 97 pp.

16. Zarif, G. and E.M. Hegazi. 1990. Effect of nitrogen fertilization and sugarbeet cultivars on the population of Pegomya mixta vill. (Diptera: Anthomyidae). Com. Sci. \& Dev. Res. Vol. 29: 1-10. 
رد فعل بعض أصناف بنجر السكر للإصابة بالحشرات الرئيسية والمحصول النهائي

2

عادل محمد الراوي 19

$$
\begin{aligned}
& \text { ا بعهد بحوث وقاية النباتات - مركز البحوث الزراعية - الدقى - الجبزة ـ مصر. } \\
& \text { r - rعهُ بحوث الدحاصبل السكرية - مركز البحوث الزراعية - الجبزة - مصر. }
\end{aligned}
$$

أجريت تجربتان حقليتان بمحطة البحوث الزر اعية بسخا - محافظة كفر الثيخ لار اسة

اختبار حساسية 11 صنف من بنجر السكر لإصابتهم بالحشرات الرئيسية ( ذبابة أوراق البنجر ،

خنفساء البنجر السلحفائية وفر اشة البنجر) وكذلك على المحصول وجودته خلال موسمين متتالين

2010/2009 و2011/2010. و اشتملت الدراسة على خمسة أصناف من بنجر السكر وحيدة الأجنة

(Pleno, وعدد ستة أصناف عديدة الأجنة (Univers, Sibel, Revel, Helsinki, Francesca) .Maghrible, Hercule, Helioses, Farida, Diamond)

$$
\text { و أوضحت النتائج المتحصل عليها ما يلي: }
$$

أن صنفي البنجر Helsinki, Hercule كانوا أقل إصابة بذبابة البنجر وعلى الجانب الآخر

وجد أن الثلاثة أصناف Helioses, Francesca, Helsinki كانو ا أقل إصابة بخنفساء البنجر السلحفائية وأن الثلاث أصناف Francesca, Sibel, Helsinki كانو ا أقل إصابة بفر اشة البنجر.

وكنتيجة نهائية لهذا البحث فقد وجد أن صنفي البنجر Revel, Maghrible كانا متوسطي

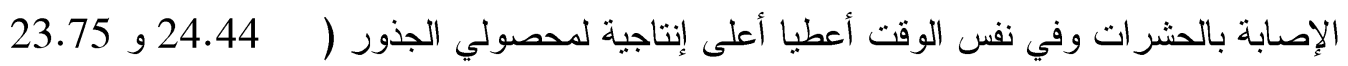

طن/فدان بالتزتيب) و السكر (4.46 و 4.39 طن/فدان بالتزنيب). 